tural Engineers, Association of Scientific Workers, Institution of Mechanical Engineers and the Institute of Chemistry. The deputation clearly had as its object the views expressed in the leading article in NATURE of July 18.

\section{Statistical ('Quality') Control of Production}

Sir Charles Darwin, director of the National Physical Laboratory, was the principal guest at the July meeting of the Scientific Instrument Manufacturers' Association of Great Britain, and spoke after luncheon about the use of statistical methods in the control of machine-production. He described some developments of these methods in massproduction in the United States; and the encouraging practical outcome of the discussion on the subject in April held at the Institution of Mechanical Engineers (see Nature, May 23, p. 573). 'Quality control', as contrasted with simple 'limit' gauging (go or not-go) and the rigid specification of tolerances, applies the principles of the law of errors towards obtaining advance information of the tendencies in course of machine production, and towards correlating the users' requirements with manufacturing economy. Sir Charles gave impressive illustrations of practical results following adoption of this method.

Makers of scientific instruments are not ordinarily affected by considerations introduced by mass pro. duction methods; and there was some tendency to question the applicability of statistical method to quantities such as they usually handle. There was, however, considerable interest in its possibilities in regard to the quantities in which they are now making many military instruments. Several speakers attached much importance to letting the operatives see their working charts, describing the stimulus value of bringing home to the workers the results of the work they are doing. There was a suggestion that the service inspection departments stand in greater need of education in statistical principles than do the manufacturers; but the speaker was reassuring about official sympathy in this direction.

\section{British and Russian Naturalists}

The following telegram was received by the Linnean Society of London from the Moscow Naturalists' Society on July 11 : “Linnean Society, London. Council of Moscow Naturalists of which Charles Darwin was honorary member has been instructed by its members assembled at meeting in commemoration of centenary of appearance of his Origin of Species to convey their ardent greetings to Linnean Society. In midst this great ordeal which has fallen to lot of democratic countries and of science Moscow Naturalists' Society oldest scientific society in Soviet Union pays reverent tribute to memory great scientist and humanist and firmly believes in early victory of our countries over Hitler tyranny". Academician Alexander Fersman, Professor Serge Ogneff, Professor Vera Varsanofieva (vice-presidents), Professor Serge Lipshitz (Secretary).

The following telegram was sent by the Linnean Society of London in reply on July 16: "Moscow Naturalists' Society, Moscow. The Linnean Society of London heartily reciprocates your friendly greetings and joins in tribute to memory of Charles Darwin most illustrious member on our roll. The magnificent resistance of the Russian people to Nazi aggression has aroused deopest admiration in our country. We share your confidence in early victory of the United Nations and are with you to the end". E. S. Russell (President).

\section{Polish Science and Learning}

Atrocity follows atrocity so rapidly on the continent of Europe that public conscience is only momentarily aroused by any fresh crime made in the name of the Nazi 'New Order' in Europe. The Polish nation has been the special object of German fury, and Polish scholars and men of science in exile feel it is their duty to remind others of what is at stake. Polish Science and Learning, which resembles Nauka Polska (Polish Science) that recorded during 1919-39 the trends and progress of general and natural science, has been founded by a group of Polish savants now working in Great Britain and representing seventeen universities, academies and research institutes. Its object is to record the continuation of their researches as well as to direct attention to events in their unhappy country, where all universities and colleges and indeed all educational establishments above primary schools have been closed. Of the hundreds of periodicals covering all branches of pure and applied science, not one is left. Practically the whole of the rich Polish literature is denied to the nation to-day. In 1940 the Germans issued a 49-page list of books banned from all libraries in Poland. It included the names of 1,500 authors and the number of works cited was about five thousand. Meanwhile, Polish university life is being maintained in Britain and the United States. Many professors and lecturers are carrying on researches at British universities and institutions, and an imposing list of publications has already resulted. In addition, a complete Polish Medical School was established at Edinburgh in 1941. Also, an autonomous Polish Institute of Science and Learning has been set up in New York to act as a publication centre and to arrange courses of lectures and discussions. There is thus a continuity of Polish scientific work, and a body of savants is ready to resume duties at home when their land is liberated.

\section{Cotton Research in East Africa}

The report of the administrative council of the Empire Cotton Growing Corporation submitted to the twenty-first annual general meeting on June 2 refers to a report by the Scientific Advisory Committee which outlines a scheme for the establishment by the Corporation of a Central Cotton Research Station in Uganda. Careful examination of the work being done by the present experiment stations has confirmed the view expressed in last year's report as to the value for the Empire of such a station in East Africa, at which fundamental scientific investigations could be carried out arising from practical problems that confront cotton-growing in those Dominions and Colonies in which the crop is cultivated on a com. mercial scale. The functions of such a station are defined as to carry out research on problems of cotton growing, especially on those of common interest to several territories. Such work should have a practical bearing on cotton production, and cotton should be treated as an element in peasant agriculture, compatible with food production, the prevention of erasion and the maintenance of soil fertility. Its functions would also include the co-ordination of certain activities of the Corporation's atations elsewhere in Africa, and if requested, of stations working 